\title{
Changes in yield and nutritive value of red clover (Trifolium pratense L.) and Festulolium (Festulolium braunii (K. Richt) A. Camus) under drought stress
}

\author{
Mariola Staniak \\ Institute of Soil Science and Plant Cultivation - State Research Institute, Department of Forage Crop Production, \\ Czartoryskich 8 Str., 24-100 Puławy, Poland \\ e-mail: staniakm@iung.pulawy.pl
}

\begin{abstract}
The aim of the research was to assess the impact of water stress on the yield and content of basic nutrients in the biomass of Trifolium pratense and Festulolium braunii cultivated in pure stand and in mixture. A pot experiment was carried out in 2012-2014, at two levels of soil moisture: well-watered and drought stress. The study showed that stress significantly reduced the dry matter yield (DMY), the most in T. pratense, followed by mixture, and F. braunii. The effect of drought stress on the nutritive value was considerable less pronounced than the influence on DMY. No significant influence of water deficit on crude protein, crude fibre and crude ash contents was found, but only on water-soluble carbohydrate and crude fat content in one year of the study. It was found, that under drought stress T. pratense is more suitable for cultivation in the mixture with $F$. braunii than in pure stand, due to a lower reduction of DMY and no adverse effect of water deficiency on yield quality.
\end{abstract}

Key words: grass, legume, mixture, water stress, chemical composition

\section{Introduction}

The importance of legumes in Europe is increasing, especially in the context of the increasing prices of energy, nitrogen fertilizers, and feed concentrates (Crews and Peoples 2005). Small-seed legumes produce a high yield of dry matter and protein, which is particularly important in nitrogen-poor habitats. Trifolium pratense (L.) is widely sown for forage in Europe because of its high yield of digestible organic matter, metabolizable energy and protein (Peyraud et al. 2009). T. pratense is usually sown with grasses rather than in pure stand because this leads to higher DMY and greater stability of yield, more efficient use of nitrogen in sward and less risk for yielding in case of failure of red clover (Hakala and Jauhiainen 2007, Gaudin et al. 2013). Fodder production in grassland is largely dependent on water availability (Hopkins and Del Prado 2007). Climate change in recent years has contributed to a reduction in rainfall and snowfall, resulting in deepening water deficit in the soil and increasing incidence of droughts, especially in summer (Schindler et al. 2007, Trenberth 2011). Water shortages in the soil worsen the conditions for plants growth and development, and consequently for crop yielding. According to Lipiec et al. (2013), abiotic stresses, such as drought and high temperature, limit the growth of root nodules in legumes, and inhibit nitrogenase activity, thus reducing nitrogen fixation. This results in a decrease in the yield of legumes and their accompanying grasses, as has been reported by many authors (Farooq et al. 2009, Jaleel et al. 2009, Rumasz-Rudnicka 2010).

The water needs of plants are related to the species and to the development stage. T. pratense has a high water demand. It uses twice as much water to produce 1 dry matter unit compared to cereal crops. This species needs 500-600 mm of annual precipitation to properly develop, including 350-460 mm during vegetation period (Rojek 1989). According to Chmura et al. (2009), under rainfall lower than optimal, the reduction of DMY may range from 3 to $34 \%$. The highest water needs of $T$. pratense are observed during the period of intensive growth (formation of main and lateral shoots) and inflorescence formation. Water shortages in this stage inhibit the growth of stem and leaf weights and contribute to poor pollination of plants by insects due to the lack of nectar. Grasses also have high water needs. High yields in the field, exceeding 10-15 t of dry matter per hectare, can be obtained only if the nutritional and water needs of the plants are met. After the soil has been fully covered, the grass demand for water equals potential evapotranspiration (Grabarczyk 1989).

Field crops respond to stress conditions caused by water scarcity in the soil with the reduction of the yield. This reaction results from the inhibition of the photosynthesis process and from disturbances in the transport and distribution of assimilates from leaves to other organs (Blum 2011). Studies carried out by various authors confirm a decrease in the yield of legumes and forage grasses under stress conditions, while the knowledge on the influence of drought on the chemical composition and nutritional value of legumes and grasses is inconsistent and 
limited. In the study of Olszewska (2004), water scarcity in soil caused an increase in total protein content and a decrease in crude fibre (CF) and crude ash (CA) content in Trifolium repens (L.). In turn, in the research by Pawlus et al. (1993), the protein concentration in T. pratense, T. repens and Trifolium resupinatum (L.) decreased under lower soil moisture. Peterson et al. (1992) described an increased detergent fibre concentration and a minor effect on crude protein (CP) concentration in different forage legumes. In contrast, Küchenmeister et al. (2013) found a decrease in CP and CF fractions concentration and also an increase in water-soluble carbohydrates (WSC) in six legumes under strong drought stress. The response of fodder grasses to water shortages is also ambiguous. Staniak (2016) and Olszewska (2009) showed an increase in the total protein content and a decrease in the CF content, while Jurkowska et al. (1993) presented a lower protein concentration under stress conditions. This information showed that more research is needed to gain knowledge about the influence of drought stress on nutritive value of forage legumes and grasses. The objective of this study was to determine the effect of water shortage on DMY and important parameters of nutritive value: CP, CF, WSC, crude fat (CFa), and CA in dry matter of T. pratense and F. braunii grown in pure stand and in mixture. We hypothesized that the effect of the long-term water stress on yield and change in quality parameters of dry matter would differ among species and cultivation methods.

\section{Materials and methods}

\section{Experimental set-up, plant material and growth conditions}

The study was conducted during the years 2012-2014. A pot experiment was established in the completely randomized block method, with four replicates, in the vegetation hall in Puławy, Poland $\left(51^{\circ} 24^{\prime} 59^{\prime \prime} \mathrm{N} 21^{\circ} 58^{\prime} 09^{\prime \prime} \mathrm{E}\right)$. Festulolium hybrid (Festulolium braunii [K. Richt] A. Camus) cultivar Agula and red clover (Trifolium pratense L.) tetraploid cultivar Bona were grown in pure stands and in mixture ( $50 \%$ grass $+50 \%$ legume). The plants were sown on $11^{\text {th }}$ April 2012, in Mitcherlich pots filled with $7 \mathrm{~kg}$ of light silty loam from arable layer $(0-30 \mathrm{~cm})$. The content (in $\mathrm{mg}$ per $100 \mathrm{~g}$ of the soil) of available phosphorus was 12.0, potassium 35.5, magnesium 17.1 and $\mathrm{pH}_{\mathrm{KCl}} 6.74$. The pots were fertilized with $0.5 \mathrm{~g} \mathrm{~N}, 1.0 \mathrm{~g} \mathrm{P}, 1.5 \mathrm{~g} \mathrm{~K}, 0.5 \mathrm{~g} \mathrm{Mg}$ in the form of solutions: $\mathrm{NH}_{4} \mathrm{NO}_{3}, \mathrm{KH}_{2} \mathrm{PO}_{4}, \mathrm{~K}_{2} \mathrm{SO}_{4}$ and $\mathrm{MgSO}_{4} \times 7 \mathrm{H}_{2} \mathrm{O}$ before sowing and in the springs of 2013 and 2014, and $0.5 \mathrm{~g} \mathrm{~N}$ after each cut of $F$. braunii in pure stand and half of this dose after each cut of mixture. T. pratense in pure stand was not fertilized by $\mathrm{N}$ (except of start dose). Fifteen seeds were sown in each pot, and after emergence some seedlings were removed, leaving 8 plants per pot (in mixture -4 units of grass and 4 units of legume). After sowing, the pots were placed outdoors during the day and protected by glass roof during rain and by night.

Plants were cultivated at two soil moisture levels: $70 \%$ field water capacity (FWC) as an optimum moisture content and 40\% FWC as a drought stress. After sowing all pots were watered the same (optimally), and after 8 weeks the soil moisture was diversified to 70 and 40\% FWC. In 2013 and 2014 soil moisture content was diverse 2 weeks after starting of vegetation. In order to maintain the appropriate soil moisture, the pots were watered daily to achieve a specified weight of the pot with soil. The treatments were finished after last cut and plants were watered as needed. To protect the experimental plants from extreme freezing temperatures, the pots were transferred to a greenhouse during winters, where the lowest temperature did not fall under $0{ }^{\circ} \mathrm{C}$. In the vegetation hall, the conditions followed a normal seasonal pattern with mild frost in winter and and we were able to control and record drought stress.

\section{Sampling and chemical analyses}

Aboveground biomass was determined by cutting the plants every 4-5 weeks in the flowering stage of T. pratense, on the height of $4-5 \mathrm{~cm}$ above the soil surface. The collection of plants was carried out three times during the first growing year (2012), and four times during second (2013) and third (2014) growing year. The harvested material was dried in a laboratory drier at $60^{\circ} \mathrm{C}$ for 72 hours, after which the DMY was measured. Chemical analyses of plant material were based on the averages for treatments (one replication) in the Certified Chemical Laboratory in Puławy. Treatments with optimal soil moisture (70\% FWC) and drought stress (40\% FWC) were included. Dry matter (DM) content was determined by weight method in $105^{\circ} \mathrm{C}, \mathrm{N}$ by Kjeldahl's method, WSC by Bertrand's method, CF by enzymatic-weight method, CFa by Soxhlet's method, and CA by conventional methods (dry mineralization). The $\mathrm{CP}$ content was calculated with the formula $\mathrm{CP}=\mathrm{N} \times 6.25$.

\section{Statistical analyses}

The results of the yields were statistically analyzed with the use of the analysis of variance using Statistica v.10.0 program. Tukey's multiple comparison test was used to compare differences between the means for main factors (soil moisture SM and treatment T), while confidence intervals for the means of LSD $(p=0.05)$ were used to compare 
the means from the subclasses (interaction $\mathrm{SM} \times \mathrm{T}$ ). The results of the chemical composition were analyzed by analyses of variance. The content of basic nutrients was analyzed separately for each year, as a non-replicate experiment (average for SM and T). The significance of differences was compared with the Tukey's test at significance level $p=0.05$. Interaction was treated as an error.

\section{Results}

The effect of the main factors - soil moisture (SM) and treatment (T) as well as that of the interaction $\mathrm{SM} \times \mathrm{T}$ on DMY, was in most cases significant $(p<0.05)$ in the regrowths and total DMY (Table 1$)$. Water deficit in the soil caused the highest decrease in the total yield of $T$. pratense cultivated in pure stand in the first and second growing years by $34.9 \%$ and $33.7 \%$, respectively.

Table 1. Dry matter yield (DMY) of Trifolium pratense and Festulolium braunii grown in pure stand (PS) and in mixture (MX) under optimal and drought stress conditions $\left(\mathrm{g} \mathrm{pot}^{-1}\right)$

\begin{tabular}{|c|c|c|c|c|c|c|c|c|}
\hline & \multicolumn{2}{|c|}{ I regrowth } & \multicolumn{2}{|c|}{ II regrowth } & \multicolumn{2}{|c|}{ III regrowth } & \multicolumn{2}{|c|}{ IV regrowth } \\
\hline Treatment & & & & soil moistu & conditions & & & \\
\hline & optimum & stress & optimum & stress & optimum & stress & optimum & stress \\
\hline \multicolumn{9}{|l|}{2012} \\
\hline T. pratense $\mathrm{PS}^{1}$ & $37.1 \pm 1.39$ & $22.9 \pm 2.64$ & $21.3 \pm 2.54$ & $14.0 \pm 0.27$ & $12.0 \pm 2.29$ & $9.0 \pm 0.31$ & - & - \\
\hline F. braunii PS & $17.9 \pm 1.24$ & $21.3 \pm 2.40$ & $15.7 \pm 0.50$ & $16.7 \pm 1.20$ & $12.2 \pm 0.58$ & $10.6 \pm 0.42$ & - & - \\
\hline $\begin{array}{l}\text { T. pratense+ F. braunii } \\
\mathrm{MX}\end{array}$ & $23.9 \pm 1.73$ & $23.5 \pm 1.37$ & $19.1 \pm 1.53$ & $16.0 \pm 1.47$ & $11.5 \pm 0.51$ & $9.4 \pm 0.72$ & - & - \\
\hline $\mathrm{LSD}_{0.05}$ & \multicolumn{2}{|c|}{2.93} & \multicolumn{2}{|c|}{2.64} & \multicolumn{2}{|c|}{ n.s. ${ }^{3}$} & & \\
\hline ANOVA summary & F-ratio & $p$ & F-ratio & $p$ & F-ratio & $p$ & - & - \\
\hline Soil moisture SM & 32.18 & $<0.001$ & 27.63 & 0.001 & 26.85 & $<0.001$ & - & - \\
\hline Treatment T & 83.25 & $<0.001$ & 2.42 & 0.061 & 2.19 & 0.062 & - & - \\
\hline $\mathrm{SM} \times \mathrm{T}$ & 66.02 & $<0.001$ & 15.77 & 0.001 & 1.02 & 0.073 & - & - \\
\hline \multicolumn{9}{|l|}{2013} \\
\hline T. pratense PS & $47.6 \pm 3.48$ & $31.9 \pm 3.13$ & $23.6 \pm 3.58$ & $15.0 \pm 1.99$ & $21.8 \pm 2.23$ & $13.8 \pm 0.14$ & $18.8 \pm 3.58$ & $13.5 \pm 1.10$ \\
\hline F. braunii PS & $25.1 \pm 1.24$ & $21.4 \pm 0.84$ & $14.4 \pm 1.15$ & $11.7 \pm 0.34$ & $11.9 \pm 0.83$ & $8.5 \pm 0.11$ & $18.0 \pm 0.77$ & $13.2 \pm 0.57$ \\
\hline $\begin{array}{l}\text { T. pratense+ F. braunii } \\
\mathrm{MX}\end{array}$ & $43.5 \pm 2.62$ & $30.3 \pm 4.40$ & $18.9 \pm 3.36$ & $14.6 \pm 1.64$ & $20.8 \pm 1.75$ & $14.0 \pm 1.46$ & $17.6 \pm 1.51$ & $14.7 \pm 1.11$ \\
\hline $\mathrm{LSD}_{0.05}$ & \multicolumn{2}{|c|}{5.13} & \multicolumn{2}{|c|}{ n.s. } & \multicolumn{2}{|c|}{2.44} & \multicolumn{2}{|c|}{ n.s. } \\
\hline ANOVA summary & F-ratio & $p$ & F-ratio & $p$ & F-ratio & $p$ & F-ratio & $p$ \\
\hline Soil moisture SM & 88.74 & $<0.001$ & 30.03 & $<0.001$ & 121.72 & $<0.001$ & 43.02 & $<0.001$ \\
\hline Treatment T & 77.28 & $<0.001$ & 14.71 & 0.049 & 80.72 & $<0.001$ & 44.24 & 0.055 \\
\hline $\mathrm{SM} \times \mathrm{T}$ & 9.92 & $<0.001$ & 3.48 & 0.055 & 6.23 & $<0.001$ & 17.76 & 0.061 \\
\hline \multicolumn{9}{|l|}{2014} \\
\hline T. pratense PS & $30.3 \pm 5.23$ & $29.2 \pm 2.49$ & $32.0 \pm 7.12$ & $23.9 \pm 0.70$ & $22.5 \pm 4.24$ & $13.3 \pm 1.39$ & $13.0 \pm 1.77$ & $9.1 \pm 3.84$ \\
\hline F. braunii PS & $18.2 \pm 1.33$ & $18.8 \pm 3.08$ & $22.4 \pm 0.77$ & $19.0 \pm 1.88$ & $15.6 \pm 1.16$ & $13.3 \pm 0.76$ & $14.1 \pm 1.22$ & $11.9 \pm 0.99$ \\
\hline $\begin{array}{l}\text { T. pratense+ F. braunii } \\
\mathrm{MX}\end{array}$ & $31.3 \pm 4.07$ & $29.1 \pm 1.70$ & $27.2 \pm 4.18$ & $21.9 \pm 0.76$ & $20.1 \pm 1.78$ & $15.8 \pm 1.40$ & $17.2 \pm 1.94$ & $13.1 \pm 1.53$ \\
\hline $\mathrm{LSD}_{0.05}$ & \multicolumn{2}{|c|}{ n.s. } & \multicolumn{2}{|c|}{ n.s. } & \multicolumn{2}{|c|}{3.83} & \multicolumn{2}{|c|}{ n.s. } \\
\hline ANOVA summary & F-ratio & $p$ & F-ratio & $p$ & F-ratio & $p$ & F-ratio & $p$ \\
\hline Soil moisture SM & 0.46 & 0.208 & 15.16 & $<0.001$ & 36.95 & $<0.001$ & 15.64 & 0.015 \\
\hline Treatment T & 32.67 & $<0.001$ & 8.57 & $<0.001$ & 7.01 & $<0.001$ & 7.61 & $<0.001$ \\
\hline $\mathrm{SM} \times \mathrm{T}$ & 0.37 & 0.063 & 0.89 & 0.055 & 5.55 & 0.001 & 0.45 & 0.061 \\
\hline
\end{tabular}


When grown in a mixture with F. braunii, the DMY reduction was smaller, but also statistically significant (by 10.1 and $26.8 \%$, respectively). In the third year of the study, the total DMY of T. pratense decreased under stress by $22.7 \%$ in pure stand and by $16.6 \%$ in the mixture, with no statistically proven differences (Fig. 1). The most resistant to drought was the hybrid of $F$. braunii cultivated in pure stand, for which no significant decrease in yield was recorded under water scarcity conditions. The analysis of regrowths showed that stress, to a similar extent, reduced the DMY of the tested crops in the first (from 15.9\% to 17.0\%) and the second growing year (from 24.9\% to $32.5 \%)$, while a higher difference was noted in the third year, when a smaller yield decrease was observed in the first and fourth regrowth (by $6.8 \%$ and $13.7 \%$, respectively), than in the second and third regrowth (by $23.7 \%$ and $22.2 \%$, respectively) (Table 1 ).

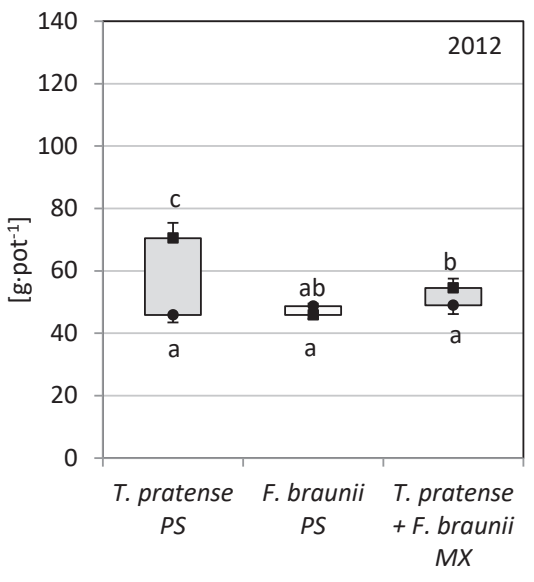

- yield in optimal soil moisture

- yield in drought stress

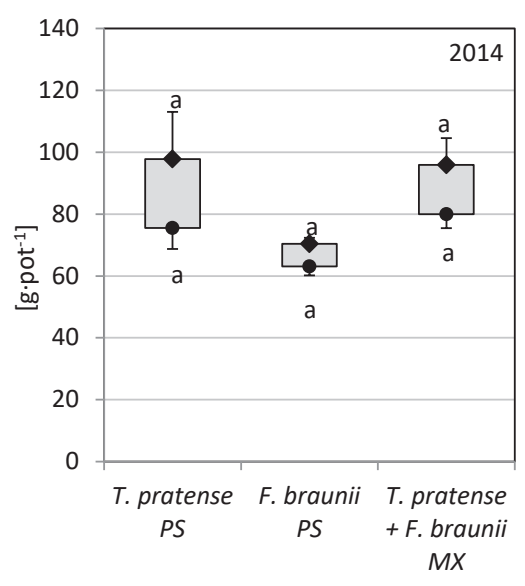

- yield in optimal soil moisture

- yield in drought stress

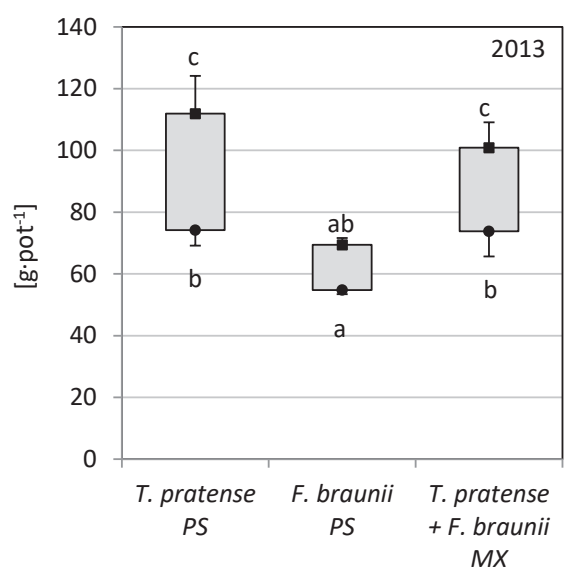

- yield in optimal soil moisture

- yield in drought stress

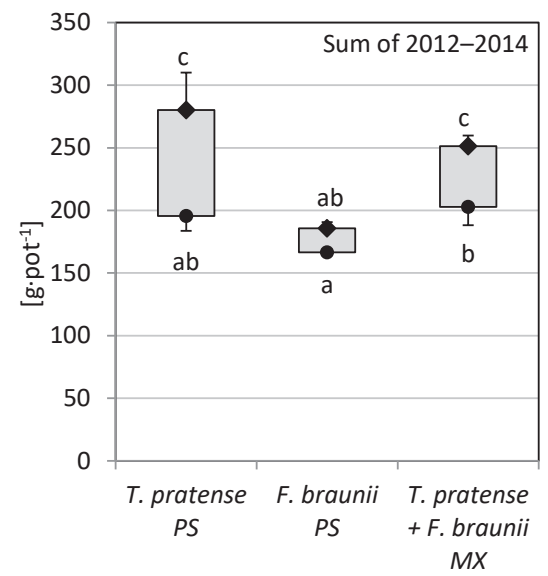

- yield in optimal soil moisture

- yield in drought stress

Fig. 1. Decrease of total DMY in 2012 (sum of three cuts), 2013 and 2014 (sum of four cuts) of Trifolium pratense and Festulolium braunii grown in pure stand (PS) and in mixture (MX) under conditions of drought stress. Different letters on bars represent significant differences among treatments (Tukey's test, $p<0.001$ ); Bars $=$ Standard Deviation

Drought stress had a much smaller effect on nutrient content in dry matter than on the yield of $T$. pratense and $F$. braunii, being in general statistically insignificant (Table 2). In the conditions of water scarcity in the soil, the tested species, regardless of the cultivation method, were characterized by similar content of CP and CF. 
Table 2. Nutritional content of Trifolium pratense and Festulolium braunii grown in pure stand (PS) and in mixture (MX) under optimal and drought stress conditions ( $\left.\mathrm{g} \mathrm{kg}^{-1} \mathrm{DM}\right)$

\begin{tabular}{|c|c|c|c|c|c|c|c|c|c|c|c|c|c|c|c|c|}
\hline Treatment & $\begin{array}{c}\text { Soil } \\
\text { moisture }\end{array}$ & & $\mathrm{CP}^{4}$ & & & $\mathrm{CF}^{5}$ & & & $\mathrm{WSC}^{6}$ & & & $\mathrm{CFa}^{7}$ & & & $C A^{8}$ & \\
\hline \multirow{3}{*}{ T. pratense $\mathrm{PS}^{1}$} & & 2012 & 2013 & 2014 & 2012 & 2013 & 2014 & 2012 & 2013 & 2014 & 2012 & 2013 & 2014 & 2012 & 2013 & 2014 \\
\hline & optimum & 188 & 186 & 171 & 209 & 200 & 216 & 35.6 & 27.3 & 46.4 & 37.2 & 39.1 & 38.9 & 115 & 125 & 92 \\
\hline & stress & 182 & 190 & 168 & 205 & 193 & 212 & 34.0 & 32.3 & 45.6 & 32.2 & 42.2 & 44.0 & 112 & 117 & 91 \\
\hline \multirow[t]{2}{*}{ F. braunii PS } & optimum & 126 & 156 & 116 & 225 & 243 & 223 & 101.4 & 51.9 & 120.2 & 35.3 & 46.7 & 42.5 & 119 & 119 & 97 \\
\hline & stress & 151 & 185 & 148 & 202 & 221 & 211 & 76.1 & 63.4 & 108.7 & 38.8 & 46.2 & 46.4 & 108 & 115 & 95 \\
\hline \multirow{2}{*}{$\begin{array}{l}\text { T. pratense+F. } \\
\text { braunii } \mathrm{MX}^{2}\end{array}$} & optimum & 143 & 174 & 119 & 224 & 229 & 226 & 78.9 & 41.0 & 106.4 & 34.4 & 43.5 & 36.9 & 110 & 114 & 102 \\
\hline & stress & 134 & 198 & 146 & 197 & 202 & 198 & 85.8 & 50.1 & 85.2 & 38.2 & 46.0 & 42.9 & 109 & 118 & 97 \\
\hline \multicolumn{17}{|c|}{ Mean for soil moisture conditions } \\
\hline Optimum & & 152 & 172 & 135 & 219 & 224 & 222 & 72.0 & 40.1 & 91.0 & 35.6 & 43.1 & 39.4 & 111 & 119 & 97 \\
\hline Stress & & 156 & 191 & 152 & 201 & 205 & 207 & 65.3 & 48.6 & 79.8 & 36.4 & 44.8 & 44.5 & 104 & 117 & 94 \\
\hline $\operatorname{LSD}(\alpha=0.05)$ & & n.s. ${ }^{3}$ & n.s. & n.s. & n.s. & n.s. & n.s. & n.s. & 8.16 & n.s. & n.s. & n.s. & 2.62 & n.s. & n.s. & n.s. \\
\hline \multicolumn{17}{|c|}{ Mean for treatment } \\
\hline T. pratense PS & & 185 & 188 & 170 & 222 & 196 & 214 & 34.8 & 29.8 & 46.0 & 34.7 & 40.6 & 41.4 & 114 & 121 & 92 \\
\hline F. braunii PS & & 138 & 170 & 132 & 234 & 232 & 217 & 88.8 & 57.6 & 114.4 & 37.0 & 46.4 & 44.4 & 114 & 117 & 96 \\
\hline $\begin{array}{l}\text { T. pratense }+F \text {. } \\
\text { braunii } \mathrm{MX}\end{array}$ & & 138 & 186 & 133 & 230 & 216 & 212 & 82.4 & 45.6 & 95.8 & 36.3 & 44.8 & 39.9 & 110 & 116 & 100 \\
\hline $\operatorname{LSD}(\alpha=0.05)$ & & n.s. & n.s. & n.s. & n.s. & n.s. & n.s. & 29.82 & 13.69 & 42.50 & n.s. & n.s. & n.s. & n.s. & n.s. & n.s. \\
\hline
\end{tabular}

${ }^{1} \mathrm{PS}=$ species grown in pure sowing; ${ }^{2} \mathrm{MX}=$ species grown in mixture; ${ }^{3} \mathrm{n} . \mathrm{s}$. $=$ not significant; ${ }^{4} \mathrm{CP}=$ crude protein; ${ }^{5} \mathrm{CF}=$ crude fibre; ${ }^{6} \mathrm{WSC}=$ water-soluble carbohydrates;

${ }^{7} \mathrm{CFa}=$ crude fat; ${ }^{8} \mathrm{CA}=$ crude ash; 2012 - the average of three regrowths; 2013 and 2014 - the average of four regrowths 
The content of WSC depended mainly on the treatment. Regardless of the soil moisture level, significantly more WSC was accumulated by the hybrid of $F$. braunii, compared to T. pratense. The mixture had by an average content of this component, but it was significantly higher in comparison to T. pratense. Taking into account the average values, the WSC content was significantly higher only in the second growing year (by $21.2 \%$ ) under drought conditions compared to optimal soil moisture. Drought stress increased the CF content, although significant differences were recorded only in the third growing year (by 12.9\%). The method of cultivation and the species did not significantly differ from the CFa content in dry matter (DM). Stress caused by water scarcity in soil also did not significantly affect the content of CA, although a tendency to decrease in CA content in stress conditions was observed in comparison with optimal conditions. Regardless of the soil moisture level, more CA was accumulated by plants in the first and second growing years (average 112 and $118 \mathrm{~g} \mathrm{~kg}^{-1} \mathrm{DM}$ ) than in the third one $\left(96 \mathrm{~g} \mathrm{~kg}^{-1} \mathrm{DM}\right)$.

\section{Discussion}

Agricultural water deficit is one of the major environmental factors causing deterioration of the conditions for growth and development of plants. This study showed that long-term water stress in the soil results in a reduction in DMY of both $T$. pratense and F. braunii, regardless of the cultivation method (pure stand or mixture). The largest decrease was observed in the DMY of T. pratense grown in pure stand followed by mixture, and F. braunii hybrid. Drought susceptibility of a species is often measured as a function of the reduction in yield under water stress (Chmura et al. 2009). Taking this criterion into account, it was found that the hybrid of $F$. braunii cultivated in pure stand was the least sensitive to long-term water deficit in the soil. T. pratense cultivated in pure stand yielded the best under optimal soil moisture conditions, however, under dry conditions, the yield loss was by $10.9 \%$ higher than when it was cultivated in the mixture with F. braunii. Similar results were obtained by the authors in other studies on the influence of long-term drought stress on the yield of Medicago and F. braunii (Staniak and Harasim 2018). Under optimum soil moisture, Medicago achieved the largest DMY when grown in a monoculture, but under drought stress, its yield losses were approximately by $13.0 \%$ higher than when it was grown in a mixture with F. braunii. It was also shown that the F. braunii hybrid grown in pure stand was the least sensitive to drought. According to Tucak et al. (2016), high sensitivity of T. pratense grown in pure stand to drought, resulted in low yield of 23 cultivars and populations. Also Gaudin et al. (2013) reported about the high sensibility of T. pratense in pure stand to drought. According to Küchenmeister et al. (2013) T. repens grown in mixture with Lolium perenne (L.) reacted to moderate stress conditions with a much smaller yield decrease (18\%) than legume in pure stand (36\%).

A higher resistance of $F$. braunii to drought stress than that of $T$. pratense may therefore be due to the different growth and development of root systems under drought conditions. The studies conducted by Skinner and Comas (2010), with 9 grasses and 6 legumes showed, that water stressed grasses generally had greater root biomass and greater proportion of roots in the 30 to $40 \mathrm{~cm}$ soil layer than did stressed legumes. Moreover, drought stress significantly reduced shoot weight (legume by $32 \%$ and grass by $20 \%$ ) but had no effect on root weight, also resulting in a greater root/shoot ratio.

The current study showed that, in the conditions of water shortage in the soil, cultivation of T. pratense in a mixture with F. braunii is beneficial from the point of view of producing feed and feeding ruminants. Namely it contributed to a significantly lower reduction of DMY compared to the pure sowing of T. pratense as well as did not significantly differentiate the content of the basic nutrients (CP, CF, CA, CFa) in the obtained biomass. Moreover, regardless of the soil moisture level, the mixture had a significantly higher WSC content in comparison to pure sowing of T. pratense, which resulted in better yields and feed uptake by the animals. The most WSC was found in the F. braunii, as it constitutes a genetic trait of this plant (intergeneric hybrid between Lolium multiflorum (Lam.) and Festuca pratensis (Huds.), inherited from the parental species L. multiflorum (Staniak 2016). The quantity and quality of $F$. braunii DMY is equal to that of $L$. multiflorum, while the more developed root system contributes to its better persistence and winter hardiness, which is in turn a characteristic taken after the second parental species, F. pratensis (Borowiecki 2002). Küchenmeister et al. (2013) showed a greater effect of moderate drought stress on DMY than on nutritional value in six species of legumes grown in pure stand and in mixture with L. perenne. Furthermore, Kuchenmeister et al. (2013) stated that the species and method of cultivation had a stronger influence on the quality parameters of biomass than water scarcity, as confirmed in this study.

Studies of different authors on the effect of drought stress on protein content in legumes and forage grasses do not give clear results. Some authors report an increase in CP content under the conditions of limited soil moisture (Olszewska 2004, Olszewska 2009, Staniak 2016), while others have reported a decrease (Jurkowska et al. 1993, Pawlus et al. 1993, Küchenmeister et al. 2013, Pimratch et al. 2013) or no significant changes in this content 
(Peterson et al. 1992, Staniak and Harasim 2018) compared to optimal conditions. According to Pimrach et al. (2013), legumes in dry conditions reduce nitrogen fixation, which translates into lower yields and lower protein content in the plant matter. The lack of clear research results may indicate the impact of other factors, such as the length and intensity of droughts, habitat conditions, temperature, and age of plants, on nutrient accumulation (Farooq et al. 2009, Jallel et al. 2009, Staniak 2016).

The CF content determines the digestibility of the feed. It varies depending on various internal factors, such as the anatomical structure, the structure of the aboveground mass, the development stage, as well as external ones, e.g. soil type, nutrient availability, the time of harvest, or weather conditions (Peterson et al. 1992, Elgersma and Søegaard 2018). According to many authors, water scarcity in the soil causes a decrease in CF content both in forage grasses (Olszewska 2009, Staniak 2016) and legumes (Peterson et al. 1992, Küchenmeister et al. 2013, Staniak and Harasim 2018). According to Buxton (1996), it results from the delayed plant ripening. Borowiecki (2002), however, demonstrated that high temperatures and rainfall shortages promote the accumulation of certain fibre fractions (cellulose, hemicellulose and lignin) in forage grasses, although with a good nitrogen supply, the nutritional value of the feed does not change significantly.

The content of WSC and their relation to the amount of total protein, determine the taste of the feed, its energy value and its usefulness for ensiling. The WSC content is a species characteristic that depends on many factors, such as the development stage and the age of the plant, season, day, and weather conditions (Staniak 2016). This study showed that regardless of the soil moisture level, more WSC was accumulated by the hybrid of $F$. braunii than by $T$. pratense, and that the mixture had a significantly higher content of WSC than legume in pure stand which has been shown to be beneficial from the feed point of view (Moorby et al. 2006). In the conditions of soil drought, in the first and third growing years, a slight decrease in the content of WSC was noted, while in the second, a significant increase in the tested species was observed. Küchenmeister et al. (2013) showed a tendency of the increase of WSC content in grasses and legumes under severe drought stress, although according to the authors, the content of this component also depended on the species and cultivation method (monoculture/mixture). According to Hoekstra and Buitink (2001), the accumulation of WSC is strongly correlated with the drought resistance of plants. A large number of stress-sensitive genes are induced by glucose, which indicates that sugars play an important role in plant responses to environmental stress (Zielińska 2012). Carbohydrates are involved in various metabolic pathways and act as signal molecules, regulating the expression of various genes, especially those involved in photosynthesis, sucrose metabolism, and osmoprotectants synthesis (Zielińska 2012). According to Saeidnia et al. (2018), the accumulation of WSC is a common adaptation in annual and perennial grasses under water stress and can be used as an indicator to distinguish drought-tolerant genotypes. This study indicated, that drought stress leads to an increase in CFa and a decrease in CA. Madziar and Latanowicz (1996) also recorded an increase in CFa under drought conditions, however they did not find any changes as regards to CA concentration.

The present experiment indicates, that under drought stress, T. pratense is more suitable for cultivation in the mixture with $F$. braunii than in pure stand, due to a lower reduction of DMY and no adverse effect of water deficiency in the soil on yield quality.

\section{References}

Blum, A. 2011. Plant breeding for water-limited environments. Springer-Verlag New York. 255 p. https://doi.org/10.1007/9781-4419-7491-4

Borowiecki, J. 2002. Wpływ nawożenia azotem na plon i wartość pokarmową Festulolium braunii odm. Felopa. Pamiętnik Puławski 131: 39-48. (in Polish).

Buxton, D.R. 1996. Quality-related characteristics of forages as influenced by plant environment and agronomic factors. Animal Feed Science and Technology 59: 37-49. https://doi.org/10.1016/0377-8401(95)00885-3

Chmura, K., Chylińska, E., Dmowski, Z. \& Nowak, L. 2009. Rola czynnika wodnego w kształtowaniu plonu wybranych roślin polowych. Infrastructure and Ecology of Rural Areas 9: 33-44. (in Polish).

Crews, T.E. \& Peoples, M.B. 2005. Can the synchrony of nitrogen supply and crop demand be improved in legume and fertilizerbased agroecosystems? A review. Nutrient Cycling in Agroecosystems 72: 101-120. https://doi.org/10.1007/s10705-004-6480-1

Elgersma, A. \& Søegaard, K. 2018. Changes in nutritive value and herbage yield during extended growth intervals in grass-legume mixtures: effects of species, maturity at harvest, and relationships between productivity and components of feed quality. Grass and Forage Science 73: 78-93. https://doi.org/10.1111/gfs.12287

Farooq, M., Wahid, A., Kobayashi, N., Fujita, D. \& Basra, S.M.A. 2009. Plant drought stress: effects, mechanisms and management. Agronomy for Sustainable Development 29: 185-212. https://doi.org/10.1051/agro:2008021

Gaudin, A.C.M., Westra, S., Loucks, C.E.S., Janovieck, K., Martin, R.C. \& Deen, W. 2013. Improving resilience of northern field crop systems using inter-seeded red clover: a review. Agronomy Journal 3: 148-180. https://doi.org/10.3390/agronomy3010148 
Grabarczyk, S. 1989. Potrzeby wodne użytków zielonych i traw. In: Dzieżyc, J. (ed.). Potrzeby wodne roślin uprawnych. Warsaw, Poland: PWN. p. 189-226. (in Polish).

Hakala, K. \& Jauhiainen, L. 2007. Yield and nitrogen concentration of above- and below-ground biomasses of red clover cultivars in pure stands and in mixtures with three grass species in northern Europe. Grass and Forage Science 62: 312-321. https://doi. org/10.1111/j.1365-2494.2007.00585.x

Hoekstra, F.A. \& Buitink, J. 2001. Mechanisms of Plant Desiccation Tolerance. Trends in Plant Science 8: 431-438. https://doi. org/10.1016/S1360-1385(01)02052-0

Hopkins, A. \& Del Prado, A. 2007. Implications of climate change for grassland in Europe: Impacts, adaptations and mitigation options: a review. Grass and Forage Science 62: 118-126. https://doi.org/10.1111/j.1365-2494.2007.00575.x

Jaleel, C.A., Manivannan, P., Wahid, A., Farooq, M., Al-Juburi, H.J., Somasundaram, R. \& Panneerselvam, R. 2009. Drought Stress in Plants: A review on morphological characteristics and pigments composition. International Journal of Agriculture and Biology 11: 100-105.

Jurkowska, H., Rogóż, A. \& Wojciechowicz, T. 1993. The content of mineral components in plants as depending on soil moisture content. Part I. Macroelements. Acta Agraria et Silvestria, Agraria 30: 29-35.

Küchenmeister, K., Küchenmeister, F., Kayser, M., Wrage-Mönnig, N. \& Isselstein, J. 2013. Influence of drought stress on nutritive value of perennial forage legumes. International Journal of Plant Production 7: 693-710.

Lipiec, J., Doussan, C., Nosalewicz, A. \& Kondracka, K. 2013. Effect of drought and heat stresses on plant growth and yield: a review. International Agrophysics 27: 463-477. https://doi.org/10.2478/intag-2013-0017

Madziar, Z., \& Latanowicz, M. 1996. Produktywność i zawartość składników pokarmowych w wybranych odmianach traw pastewnych uprawianych w warunkach wazonowych przy zróżnicowanej wilgotności gleby. PTPN, Wydział Nauk Rolniczych i Leśnych, 81: 129-135. (in Polish).

Moorby, J.M. Evans, R.T., Scollan, N.D., Mac Rae, J.C. \& Theodorou, M.K. 2006. Increased concentration of water-soluble carbohydrate in perennial ryegrass (Lolium perenne L.). Evaluation in dairy cows in early lactation. Grass and Forage Science 61: 52-59. https://doi.org/10.1111/j.1365-2494.2006.00507.x

Olszewska, M. 2004. Reaction of white clover grown on two types of soil to water stress. Acta Scientiarum Polonorum, sec. Agricultura 3: 203-213.

Olszewska, M. 2009. Response of cultivars of meadow fescue (Festuca pratensis Huds.) and timothy (Phleum pratense L.) grown on organic soil to moisture deficiency. Acta Scientiarum Polonorum, sec. Agricultura 8: 37-46.

Pawlus, M., Kitczak, T. \& Jurzysta, J. 1993. Wpływ terminu zbioru i zróżnicowanych warunków wodnych na plonowanie koniczyny czerwonej, białej i perskiej. Roczniki AR Poznań, Rolnictwo 41: 121-127. (in Polish).

Peterson, P.R., Sheaffer, C.C. \& Hall, M.H. 1992. Drought effects on perennial forage legume yield and quality. Agronomy Journal 84: 774-779. https://doi.org/10.2134/agronj1992.00021962008400050003x

Peyraud, J.L., Le Gall, A. \& Lüscher, A. 2009. Potential food production from forage legume-based-systems in Europe: an overview. Irish Journal of Agricultural and Food Research 48: 115-135.

Pimratch, S., Jogloyb, S., Vorasootb, N., Toomsanb, B. \& Kesmalab, T. 2013. Association of nitrogen fixation to water uses efficiency and yield traits of peanut. International Journal of Plant Production 7: 225-242.

Rojek, S. 1989. Potrzeby wodne roślin motylkowatych. In: Dzieżyc, J. (ed.). Potrzeby wodne roślin uprawnych. Warsaw, Poland: PWN. p. 137-158. (in Polish).

Rumasz-Rudnicka, E. 2010. Influence of irrigation and nitrogen fertilizer on assimilation and transpiration of westerwolds ryegrass. Acta Agrophysica 15: 395-408.

Saeidnia, F., Majidi, M.M., Mirlohi, A. \& Ahmadi, B. 2018. Physiological responses of drought tolerance in orchardgrass (Dactylis glomerata) in association with persistence and summer dormancy. Crop and Pasture Science 69: 515-526. https://doi. org/10.1071/CP17314

Schindler, U., Steidl, J., Müller, L., Eulenstein, F. \& Thiere, J. 2007. Drought risk to agricultural land in Northeast and Central Germany. Journal of Plant Nutrition and Soil Science 170: 357-362. https://doi.org/10.1002/jpln.200622045

Skinner, R.H. \& Comas, L.H. 2010. Root distribution of temperate forage species subjected to water and nitrogen stress. Crop Science 50: 2178-2185. https://doi.org/10.2135/cropsci2009.08.0461

Staniak, M. 2016. The impact of drought stress on the yields and food value of selected forage grasses. Acta Agrobotanica 69: 1663. https://doi.org/10.5586/aa.1663

Staniak, M. \& Harasim, E. 2018. Changes in nutritive value of alfalfa (Medicago x varia T. Martyn) and Festulolium (Festulolium braunii (K. Richt.) A. Camus) under drought stress. Journal of Agronomy and Crop Science 204: 456-466. https://doi.org/10.1111/ jac.12271

Trenberth, K.E. 2011. Changes in precipitation with climate change. Climate Research 47: 123-138. https://doi.org/10.3354/cr00953

Tucak, M., Popović, S., Čupić, T., Krizmanić, G., Španić, V., Meglič, V. \& Radović J. 2016. Assessment of red clover (Trifolium pratense L.) productivity in environmental stress. Poljoprivreda/Agriculture 22: 3-9.

Zielińska, S. 2012. Metabolizm węglowodanów jako jeden ze składników mechanizmów tolerancji na stresy abiotyczne u roślin. Kosmos Problemy Nauk Biologicznych 61: 613-623. (in Polish). 